\title{
Spatial variability in climate, phenology, and fruit composition across a reference vineyard network in Southern Oregon
}

\author{
Gregory V. Jones \\ Center for Wine Education and Department of Environmental Studies \\ Linfield College, McMinnville, Oregon, USA
}

\begin{abstract}
This paper provides a summary of observational data from a reference vineyard network in the Southern Oregon American Viticultural Area (AVA). The network was established to collect baseline data on spatial variations in temperature, grapevine phenology, and composition characteristics across a collection of varieties grown in the region. The results from the period 2003 through 2017 show a wide diversity of climate types for winegrape production ranging from relatively cool to relatively warm conditions (GST 14.8 to $17.5^{\circ} \mathrm{C}$ and GDD 1109 to 1657 ). One unique climate aspect is that the region experiences higher diurnal temperature ranges during the growing season than regions in Europe and many others in the western US. Grapevine phenological timing and intervals between events are similar to other wine regions with budbreak averaging 14Apr, flowering 14-Jun, véraison 19-Aug. However, harvest dates are up to ten days to two weeks later than many regions in Europe. Ripening period and harvest composition observations reveal the diversity of potential varieties that the region can ripen. Over all varieties, sites and vintages observed harvest composition averages $23.7^{\circ}$ Brix, $6.4 \mathrm{~g} / \mathrm{L}$ total acidity, a $\mathrm{pH}$ of 3.44 , and yields of 2.7 tons/acre.
\end{abstract}

\section{Introduction}

Within region weather and climate controls on site plant growth and fruit composition are evident in every wine region worldwide [1]. To understand spatial variations in climate, grapevine phenology and fruit characteristics numerous reference vineyard networks have been developed in regions worldwide (e.g., Bordeaux, Italy, etc.) $[2,3,4]$. The aims of reference vineyard networks are typically to document baseline characteristics in within region growth and production characteristics, the controls that landscape variations have on these characteristics, and provide growers comparative measures in a small sample of vineyards within the region.

This research describes observations from a reference vineyard network in the Southern Oregon American Viticultural Area (AVA) (Figure 1) [5]

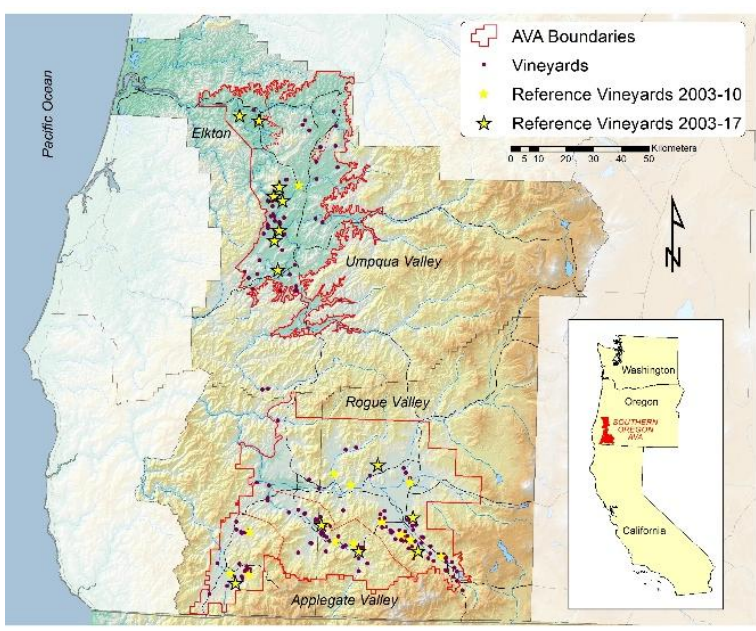

Figure 1. Location of the Southern Oregon AVA and sub-AVAs along with the reference vineyards used to monitor weather and climate, phenology, and composition described in this paper.

one of 18 regions in the state recognized and defined by the federal government based on 
geographic, historical, and cultural identity along with climate, soil, geology, and terrain uniqueness compared to surrounding areas. The Southern Oregon AVA has five sub-regions and represents approximately $24 \%$ of Oregon's production, acreage, number of vineyards, and number of wineries. The region grows over 70 different types of winegrapes ranging from cool climate varieties (e.g., Pinot Noir, Pinot Gris, Chardonnay, etc.) to warm climate varieties (e.g., Syrah, Malbec, Tempranillo), with a mix of approximately $70 \%$ red and $30 \%$ white varieties being grown. The region currently has nearly 300 growers, with nearly 3300 planted hectares, producing 25,000 tons that are crushed at 125 wineries [5].

The Southern Oregon (AVA) is one of the many winegrape producing regions found within the intermountain valleys along the west coast of the United States. The landscape of the Southern Oregon AVA is extremely diverse, coming from the joining of three mountain ranges of varying ages and structure: the Klamath and Siskiyou Mountains to the southwest to southeast, the Coastal Range to the west, and the Cascades to the east and north [5]. The Klamath Mountains extend through the south and southwestern portion of the AVA and consist of complex folded and faulted igneous and metamorphic rocks that are the oldest in the region. The Cascade Mountains to the east consist of the younger High Cascades and the older, more deeply eroded Western Cascades that make up the eastern boundary of the AVA. The region is protected from the ocean largely by the Coastal Mountains, which are composed of mostly oceanic sedimentary rocks and volcanic islands that were accreted to the landscape over the last 50 million years [5]. The Rogue Valley AVA is drained mainly by the Rogue River and its major tributaries; the Applegate River, the Illinois River, and Bear Creek, while the Umpqua Valley AVA is drained by hundreds of smaller tributaries of the North and South Umpqua Rivers.

The agricultural landscape of the Southern Oregon AVA is mostly comprised of valley lowlands with some isolated hills, stream terraces or benches, and footslopes of alluvial fans scattered by hilltops and ridges. Vineyards in the region are found on flat to very steep slopes (up to $40 \%$ or more) that are distributed along isolated hills, stream terraces or benches, and at the foot of alluvial fans. Elevations of existing vineyard sites range from approximately $60-90 \mathrm{~m}$ in the northwestern portion of the Umpqua Valley AVA to $750 \mathrm{~m}$ in the Bear Creek Valley of the Rogue Valley AVA. Most of the current vineyards are planted to $\sim 180-200 \mathrm{~m}$ in the Umpqua Valley AVA and $\sim 450-550 \mathrm{~m}$ in the Rogue Valley AVA [5].
From the diverse geology of the region comes a widely varying mix of metamorphic, sedimentary, and volcanic derived soils [5]. The lower elevations of the valleys are mostly deep alluvial material or heavy clays while the hillside and bench locations have mixed alluvial, silt, or clay structures. Complex faulting, especially in the western portion of the Rogue Valley AVA and southern portion of the Umpqua Valley AVA, can produce large variations in soil types over areas the size of a vineyard. Drainage and moisture-holding capacity vary greatly by soil type, and while most soils in the region do retain water into the growing season, available water for irrigation during mid to late summer growth is generally needed [5]. Soil fertility is generally sufficient for winegrape production but varies greatly over the region with issues generally related to either imbalances of nitrogen, calcium, potassium, phosphorous, magnesium, boron, or zinc. Soil $\mathrm{pH}$ also varies from region to region (roughly from 4.5 to 7.0 ) and is mostly due to differences in climate and parent rock material. In general, the soils in the northern and western portions of the Southern Oregon AVA are slightly more acidic than those of the south as a result of more rainfall and greater leaching potential [5].

From a climate perspective the Southern Oregon AVA offers the most diverse growing conditions in Oregon and arguably in the western United States [6]. Heat accumulation varies from cool climate suitability in the northern Umpqua Valley and Illinois Valley (1200-1350 GDD) to intermediate values in the central Umpqua Valley and Applegate Valley (1350-1500 GDD) to warm climate suitability in the Bear Creek and Rogue River region (1500-1700 GDD). The Umpqua Valley AVA in general has longer frost-free periods (180220 days) and milder growing seasons, experiencing annual precipitation values that average 750 to $1500 \mathrm{~mm}$ from south to north [5]. The Rogue Valley AVA has the higher elevations, that along with their general north-south tending valleys, and their proximity to the Pacific Ocean and intervening topographical barriers create a climate transect of wetter and cooler conditions in the western parts of the region to the warmer and drier eastern areas. Precipitation varies from 300$650 \mathrm{~mm}$ in most of the vineyard areas in the Rogue, declining in amount from west to east (all of the Southern Oregon AVA experiences less than 15 percent of the total precipitation occurring during the growing season of April through October). The frost-free growing season is shorter in the Rogue Valley AVA (145-185) due to higher elevations that bring later and earlier frost potential in the spring and fall, respectively [5].

The reference vineyard network described in this research was established in 2003 within the 
Rogue Valley AVA and in 2004 in the Umpqua Valley AVA, both sub-regions of the Southern Oregon AVA (Figure 1). The purpose of the reference vineyard network is to provide an in depth look at spatial variations in important characteristics of temperature, phenology, composition, and yields in the region. This paper will provide a description of the observations from this network during 20032017.

\section{Data and Methods}

The network was developed initially to include 29 vineyards from which temperature, phenology, and sample and harvest composition data were collected during 2003-2010. During 2011-2017 the network was reduced to 14 locations with temperature, phenology, and harvest composition data collected (no sampling was done). All participating vineyards were chosen based upon their spatial and elevational representation in the Southern Oregon AVA and willingness to participate and observe phenology in a consistent manner (using the Modified E-L System) [2]. The reference vineyards are spread out over a $110 \mathrm{~km}$ east-west and $240 \mathrm{~km}$ north-south area across a range of landscapes with a mean elevation of $391 \mathrm{~m}$, ranging from $103 \mathrm{~m}$ to $611 \mathrm{~m}$ (Figure 1). At each reference vineyard site temperature devices were installed at $1.5 \mathrm{~m}$ height in a standard housing and set to record at 15 minute intervals during both the dormant (Nov 1-Mar 31) and growing seasons (Apr 1-Oct 31). Each year the data was downloaded and the observations were then aggregated to hourly and daily average, maximum, and minimum values, along with standard growing degree-days (GDD) and summarized by site, sub-region, and region. For phenological observations, the four main events of budbreak, bloom, véraison, and harvest for a collection of varieties (i.e., Cabernet Franc, Chardonnay, Merlot, Pinot Gris, Pinot Noir, Sangiovese, Syrah, Tempranillo, Viognier, Grenache, Malbec, and Riesling) commonly grown across the region were submitted by growers (not all varieties are grown at every site). The phenological data were then examined for average dates and intervals between dates for the entire region, sub-regions, and by variety. During the 2004-2010 period a "snapshot of ripening" 100 berry sample was collected from the same vines during 13-15 September for each variety and site. The samples were then analyzed for ${ }^{\circ}$ Brix, titratable acidity, $\mathrm{pH}$, and berry weights using standard industry methods. Finally, harvest composition values for ${ }^{\circ}$ Brix, titratable acidity, $\mathrm{pH}$, and yields were submitted by growers at the end of the season and summarized by region and variety for the entire time period of 2003-2017. The results will detail both the temporal and spatial variability in the weather/climate, phenology, fruit composition and harvest characteristics across the Southern Oregon
AVA. Below the general climate, phenology and harvest composition characteristics are presented for the 14 locations for the entire time period (20032017) and the sampling characteristics for the entire 29 locations during 2003-2010.

\section{Results}

For the dormant season from November through March, the 14 locations exhibit an average temperature of $5.7^{\circ} \mathrm{C}$ ranging 2 degrees across the locations (Table 1). Maximum temperatures during the winter average $11.6^{\circ} \mathrm{C}$ across the region however they did occur as high as 18.7 to $33.2^{\circ} \mathrm{C}$ during warm fall periods. Minimum temperatures across the network during the winter drop below freezing on average 53 times with the warmer sites experiencing as few as 27 and the colder sites experiencing as many as 87. However, while average minimum temperatures remain above freezing $\left(1.5^{\circ} \mathrm{C}\right)$ absolute minimums dropped as low as -3.4 to $-21.8^{\circ} \mathrm{C}$ during the 2003-2017 period.

Table 1. Dormant season (November through March) for 14 locations with data during 2004-2017

\begin{tabular}{|l|c|c|c|c|}
\hline Variable & Mean & STD & Max & Min \\
\hline DTavg $\left({ }^{\circ} \mathrm{C}\right)$ & 5.7 & 0.7 & 6.7 & 4.7 \\
\hline DTmax $\left({ }^{\circ} \mathrm{C}\right)$ & 11.6 & 0.7 & 13.0 & 10.4 \\
\hline DAbsTmax $\left({ }^{\circ} \mathrm{C}\right)$ & & & 33.2 & 18.7 \\
\hline DTmin $\left({ }^{\circ} \mathrm{C}\right)$ & 1.5 & 1.3 & 3.1 & -0.4 \\
\hline DAbsTmin $\left(\left({ }^{\circ} \mathrm{C}\right)\right.$ & & & -3.4 & -21.8 \\
\hline \# Days $<0^{\circ} \mathrm{C}$ & 53 & 22 & 87 & 27 \\
\hline
\end{tabular}

For the April through October growing season the 14 locations have a climate maturity type that ranges from a cool to warm climate [6], averaging $16.3^{\circ} \mathrm{C}$ or an intermediate climate (Table 2). GDD averages 1412 for the locations, ranging from 1109 to 1657 or a Region Ia to nearly a Region III on the Winkler Index [6]. Maximum temperatures during the vintage average $26.1^{\circ} \mathrm{C}$ but the absolute maximums were observed to range from 35.3 to $47.0^{\circ} \mathrm{C}$ across the locations. The number of days above $35^{\circ} \mathrm{C}$ average as low as 8 per year to as many as 48 per year. While minimum temperatures across the region average $8.0^{\circ} \mathrm{C}$ during the growing season, temperatures dropped as low as $-6.3^{\circ} \mathrm{C}$ in early April during one vintage. Most sites experience frost days during the growing season with an average of 7 per year, ranging from a low of 0 to a high of 19 at the coolest location. The last spring frost $\left(0^{\circ} \mathrm{C}\right)$ averages $14-\mathrm{Apr}$ across the sites with a standard deviation of $+/-25$ days during the 2004 through 2017 vintages. The first fall frost $\left(0^{\circ} \mathrm{C}\right)$ averages 27 -Oct for the 14 sites varying +/18 days during the observation period. The result is an average frost-free period of 197 days with a range of 149 to 236 days across these 14 locations. Finally, the growing season diurnal temperature range (DTR) averages $18.4^{\circ} \mathrm{C}$ across these sites. Other work examining only the August and 
September months finds that the region has a $22.4^{\circ} \mathrm{C}$ average DTR during ripening [5].

Table 2. Growing season (April through October) for 14 locations with data during 2004-2017

\begin{tabular}{|l|c|c|c|c|}
\hline Variable & Mean & STD & Max & Min \\
\hline GSTavg $\left({ }^{\circ} \mathrm{C}\right)$ & 16.3 & 0.7 & 17.5 & 14.8 \\
\hline GSTmax $\left({ }^{\circ} \mathrm{C}\right)$ & 26.1 & 1.4 & 28.2 & 23.1 \\
\hline GSAbsTmax $\left({ }^{\circ} \mathrm{C}\right)$ & & & 47.0 & 35.3 \\
\hline GSTmin $\left({ }^{\circ} \mathrm{C}\right)$ & 8.0 & 1.2 & 9.4 & 5.7 \\
\hline GSAbsTmin $\left({ }^{\circ} \mathrm{C}\right)$ & & & 3.4 & -6.3 \\
\hline GSDTR $\left({ }^{\circ} \mathrm{C}\right)$ & 18.4 & 0.9 & 19.1 & 17.5 \\
\hline GDD $\left(\mathrm{C}^{\circ}\right)$ & 1412 & 138 & 1657 & 1109 \\
\hline \# Days $>35^{\circ} \mathrm{C}$ & 27 & 12 & 48 & 8 \\
\hline \# Days $<0{ }^{\circ} \mathrm{C}$ & 7 & 6 & 19 & 0 \\
\hline Last Spring $\left(0^{\circ} \mathrm{C}\right)$ & $14 \mathrm{Apr}$ & 25 & $22 \mathrm{May}$ & $3 \mathrm{Jan}$ \\
\hline First Fall $\left(0^{\circ} \mathrm{C}\right)$ & $27 \mathrm{Oct}$ & 18 & $7 \mathrm{Dec}$ & $24 \mathrm{Sept}$ \\
\hline Frost-Free $($ Days $)$ & 197 & 28 & 236 & 149 \\
\hline
\end{tabular}

Table 3 details the phenological characteristics across the entire 2003-2017 time period including all sites (29) and varieties (12) with observations. Budbreak occurs on average 14-Apr, but has been as early as 8-Mar and as late as 1-Jun. The earliest variety in the region to break bud is typically Chardonnay (12-Apr), while the latest is commonly Tempranillo (18-Apr). Flowering has occurred as early as 30-Apr and as late as 14-Jul, averaging 14Jun. On average the earliest flowering varieties are Chardonnay and Pinot Noir (8-Jun) and the latest is Grenache (21-Jun). Véraison averages 19-Aug across the network but has been observed as early as 13-Jul and as late as 23-Sep. The earliest varieties to experience véraison on average are Pinot Gris and Tempranillo (13-Aug) and the latest on average is Grenache (28-Aug). Harvest dates average 8-Oct across the sites, varieties and vintages (Table 3) however harvest has occurred as early as 23-Aug (early vintage and variety) and as late as 30 -Nov. Chardonnay is on average the first to harvest (2-Oct) along with Pinot Noir and Tempranillo (6-Oct) while Cabernet Franc and Sangiovese are on average the latest to harvest (17Oct). During the 2003-2017 vintages the budbreak to flowering interval averaged 61 days, budbreak to véraison averaged 126 days, and budbreak to harvest 172 days (Table 3). Flowering to véraison averaged 64 days while flowering to harvest averaged 112 days. Véraison to harvest averages 49 days across these locations. Each of these intervals vary +/- 8-13 days across sites, vintages and varieties.

Table 4 displays summary statistics for a 'snapshot of ripening' 100 berry sample from the same vines at each location, across twelve varieties, during seven years (2004-2010), and on the same days (1315 September). Ripening tends to progress to 18.4 ${ }^{\circ}$ Brix on average by mid-September, with $+/-2.4$ ${ }^{\circ}$ Brix across sites and varieties. ${ }^{\circ}$ Brix has ranged from as low as 11.3 (cool year and site) to 22.8 (warm year and site) with Pinot Gris and Tempranillo having higher ${ }^{\circ}$ Brix while Grenache and Riesling were the lowest. Titratable acidity from the sampling averages $11.9 \mathrm{~g} / \mathrm{L}$ varying $+/$ $4.2 \mathrm{~g} / \mathrm{L}$ across sites and varieties. Merlot and Pinot have the lowest average TA at this time while Riesling and Grenache are the highest. By midSeptember $\mathrm{pH}$ across varieties and sites averages 3.09 varying $+/-0.17$ (Table 4). Tempranillo has the highest average $\mathrm{pH}$ by this time with Sangiovese, Grenache and Riesling having the lowest average pH. Samples of 100 berries exhibit an average of $130.4 \mathrm{~g}$, ranging $31.7 \mathrm{~g}$ across sites, years and varieties. The smallest berry weights are consistently from Merlot and Cabernet Franc while Tempranillo and Grenache have the highest berry weights.

Table 3. Phenological statistics across all sites and varieties during 2003-2017. The number of observations per event each year averages 70-80. All dates are reported by reference vineyard growers.

\begin{tabular}{|l|c|c|c|c|}
\hline Variable & Median & STD & Max & Min \\
\hline Budbreak (BB) & $4 / 14$ & 9 & $6 / 1$ & $3 / 8$ \\
\hline Flowering (F) & $6 / 14$ & 8 & $7 / 14$ & $4 / 30$ \\
\hline Véraison (V) & $8 / 19$ & 8 & $9 / 23$ & $7 / 13$ \\
\hline Harvest (H) & $10 / 8$ & 11 & $11 / 30$ & $8 / 23$ \\
\hline $\begin{array}{l}\text { Budbreak to } \\
\text { Flowering (BB-F) }\end{array}$ & 61 & 9 & 81 & 40 \\
\hline $\begin{array}{l}\text { Budbreak to } \\
\text { Véraison (BB-V) }\end{array}$ & 126 & 10 & 155 & 105 \\
\hline $\begin{array}{l}\text { Flowering to } \\
\text { Véraison (F-V) }\end{array}$ & 64 & 8 & 87 & 50 \\
\hline $\begin{array}{l}\text { Budbreak to } \\
\text { Harvest (BB-H) }\end{array}$ & 172 & 13 & 206 & 148 \\
\hline $\begin{array}{l}\text { Flowering to } \\
\text { Harvest (F-H) }\end{array}$ & 112 & 12 & 146 & 91 \\
\hline $\begin{array}{l}\text { Véraison to } \\
\text { Harvest (V-H) }\end{array}$ & 49 & 11 & 81 & 27 \\
\hline
\end{tabular}

Table 4. Sampling composition statistics during 13-15 September each year for 2004-2010 for 29 locations in the Southern Oregon AVA. Observations come from approximately 100 samples per year

\begin{tabular}{|l|c|c|c|c|}
\hline Variable & Median & STD & Max & Min \\
\hline${ }^{\circ}$ Brix & 18.4 & 2.4 & 22.8 & 11.3 \\
\hline TA $(\mathrm{g} / \mathrm{L})$ & 11.8 & 4.2 & 25.3 & 6.6 \\
\hline $\mathrm{pH}$ & 3.09 & 0.17 & 3.51 & 2.71 \\
\hline $\begin{array}{l}\text { Weight } 100 \\
\text { berries }(\mathrm{g})\end{array}$ & 130.4 & 31.7 & 226.9 & 75.3 \\
\hline
\end{tabular}

Harvest composition across the reference vineyards show an average ${ }^{\circ}$ Brix of 23.7 that tends to range +/- 1.3 across vintages, sites, and varieties (Table $5)$. No one variety stands out with higher average ${ }^{\circ}$ Brix however Chardonnay and Riesling tend to have the lowest average ${ }^{\circ}$ Brix at harvest. Titratable acid levels at harvest average $6.4 \mathrm{~g} / \mathrm{L}$, ranging $+/$ $1.4 \mathrm{~g} / \mathrm{L}$ for individual varieties, sites or vintages. The higher average TA at harvest is generally found with Riesling and Sangiovese while the lowest is 
typically seen with Tempranillo. Harvest $\mathrm{pH}$ values average 3.44 , varying $+/-0.22$ across sites, varieties and vintages. Given its lower average TA, Tempranillo tends to have the highest average $\mathrm{pH}$ at harvest while Riesling has the lowest average $\mathrm{pH}$. Yields during 2004-2017 averaged 2.7 tons/acre with a fairly large vintage, site and variety variation of $+/-1.3$ tons/acres. Yields were reported to be on average the highest for Chardonnay and Pinot Gris and lowest for Sangiovese.

Table 5. Harvest composition statistics for 2003-2017 for all locations in the Southern Oregon AVA. Observations come from approximately 125-150 samples per year.

\begin{tabular}{|l|c|c|c|c|}
\hline Variable & Median & STD & Max & Min \\
\hline${ }^{\circ}$ Brix & 23.7 & 1.3 & 27.3 & 20.2 \\
\hline TA $(\mathrm{g} / \mathrm{L})$ & 6.4 & 1.4 & 10.2 & 3.6 \\
\hline $\mathrm{pH}$ & 3.44 & 0.22 & 4.21 & 3.02 \\
\hline Yield (tons/acre) & 2.7 & 1.3 & 7.2 & 0.7 \\
\hline
\end{tabular}

\section{Discussion and Conclusions}

The reference vineyard network in the Southern Oregon AVA was established to provide an in depth look at spatial variations in important characteristics of temperature, phenology, composition, and yields in the region. During 2003-2017 numerous aspects of winegrape growing and production have been documented providing growers baseline information for the region.

The results detail a region that has a cool winter with low to moderate winter extreme temperature risk. The growing season has average temperatures that are intermediate for winegrape production $\left(16.3^{\circ} \mathrm{C}\right)$ and growing degree-days that range from a Region Ia to a Region III on the Winkler Index (average 1412, Region II). The GDD values compare to Valtellina Superiore in Italy, Bordeaux in France, and Rioja in Spain [6]. The region experiences an average last spring frost on 14-Apr and a first fall frost on 27-Oct resulting in an average frost-free period of 197 days (ranging from 149-236 days over the sites). Furthermore, the growing season diurnal temperature range averages $18.4^{\circ} \mathrm{C}$ across the Southern Oregon reference vineyard network which is higher than a nine region study conducted in France, Spain, Germany, Italy, and Slovakia $\left(18.4^{\circ} \mathrm{C}\right.$ vs. $\left.16.1^{\circ} \mathrm{C}\right)$ and is the result of both warmer daytime maximum temperatures $\left(26.1^{\circ} \mathrm{C}\right.$ vs. $\left.21.8^{\circ} \mathrm{C}\right)$ and lower nighttime minimum temperatures $\left(8.0^{\circ} \mathrm{C}\right.$ vs. $\left.10.4^{\circ} \mathrm{C}\right)$ across the growing season [7].

Phenological observations from the network show an average regional budbreak on 14-Apr, bloom on 14-Jun, véraison on 19-Aug, and harvest on 8-Oct. These events vary 16-22 days across sites, varieties and vintages with harvest dates varying the most. The phenological timing in Southern Oregon is very similar to the averages from a 17 variety, nine region study conducted in France, Spain, Germany, Italy, and Slovakia (13-Apr, 13-Jun, 17-Aug), except for harvest which averages 10 days earlier (28-Sep) in the European regions [7]. A similar comparison can be made with an 18 variety average in Conegliano, Italy (+/- 4 days), except for harvest dates which occur two weeks earlier in the Italian region [8]. Similar bloom and véraison dates are also observed in a reference vineyard network in Bordeaux while harvest is typically one week later in Southern Oregon [9]. The interval from budbreak to harvest averages 172 days across the region, which is within the average frost-free period although the average budbreak and average last spring frost are both on 14-Apr indicating some frost risk, especially in the cooler areas in the southern portion of the AVA. Average phenological interval lengths in Southern Oregon are overall similar to average interval links from a European study across multiple varieties, regions, and countries [7]. The only differences were for bloom to harvest (108 days in Europe vs. 112 days in Southern Oregon), véraison to harvest (43 days vs. 49 days), and the overall budbreak to harvest interval (168 days vs. 172 days) [7].

Fruit composition characteristics during ripening exhibit a wide range due to vintage variations with ${ }^{\circ}$ Brix levels reaching 11.3 to 22.8 across sites and varieties. Acid levels in mid-September on average are still relatively high $(11.8 \mathrm{~g} / \mathrm{L})$ but in the warmer years have been below $8 \mathrm{~g} / \mathrm{L}$ by mid-month. $\mathrm{pH}$ values during this period average near 3.00, although have ranged from 2.71 to 3.51 during warm or cool vintages, respectively. Berry weights in mid-September range from very low weights of $100 \mathrm{~g}$ or less (per 100 berries) from Merlot and Cabernet Franc to over 200 g (per 100 berries) for Tempranillo and Grenache.

Growers and producers ripen a wide range of varieties in the region, achieving $23.7^{\circ}$ Brix, 6.4 $\mathrm{g} / \mathrm{L}, 3.44 \mathrm{pH}$, and yields of 2.7 tons/acre on average at harvest. From the mid-ripening sampling to harvest, which averages 22 days, the region typically sees increases of 5-7 ${ }^{\circ}$ Brix, a reduction of 4-6 g/L of titratable acidity, and an increase in $\mathrm{pH}$ of 0.40 to 0.60 .

The network is an ongoing research project that provides growers with information on spatial variations in climate, grapevine phenology, and composition characteristics of a young wine region in Oregon. This project summary highlights the large climatic diversity in the region, which in turn allows the region to grow over 70 different varieties of winegrapes. 


\section{References}

1.

. Jones, M. Moriondo, B. Bois, A. Hall, A. Duff, Analysis of the spatial climate structure in viticulture regions worldwide. Le Bulletin de l'OIV 82(944,945,946):507-518 (2009).

2.

. Jones. Winegrape Phenology in Phenology: An Integrative Environmental Science 2nd Edition, Mark D. Schwartz, Editor. Springer. 610 pp. (2013).

3.

Catania, M. Vallone, G. Lo Re, M. Ortolani, A wireless sensor network for vineyard management in Sicily (Italy). Agric Eng Int: CIGR Journal Open access at http://www.cigrjournal.org Vol. 15, No.4 139146, (2013).

4.

Le Roux, L. de Rességuier, T. Corpetti, N. Jégou, M. Madelin, C. van Leeuwen, $\mathrm{H}$. Quénol, Comparison of two fine scale spatial models for mapping temperatures inside winegrowing areas. Agri \& F Meteo. 247. 159169. 10.1016/j.agrformet.2017.07.020, (2017).

5.

. Jones, Southern Oregon AVA landscape and climate for wine production. Proceedings of the 11th International Terroir Congress, Linfield College, McMinnville, Oregon, pp 33-34 (2016).

6.

. Jones, A.A. Duff, A. Hall, J. Myers, Spatial analysis of climate in winegrape growing regions in the western United States. Am J Enol Viti, 61:313-326 (2010).

7.

. Jones, E. Duchene, D. Tomasi, J. Yuste, O. Braslavksa, H. Schultz, C. Martinez, S. Boso, F. Langellier, C. Perruchot, G. Guimberteau, Changes in European Winegrape Phenology and Relationships with Climate, Proceedings of the $14^{\text {th }}$ International Meeting GiESCO (2005).

8.

D.

Tomasi, G.V. Jones, M. Giust, L. Lovat, F. Gaiotti, Grapevine Phenology and Climate Change: Relationships and Trends in the Veneto Region of Italy for 1964-2009. Am J Enol Viti, 62:3(329-339) (2011).

9.

. Jones, R. E. Davis, Climate Influences on Grapevine Phenology, Grape Composition, and Wine Production and Quality for Bordeaux, France, Am J Enol Viti, 51(3):249-261, (2000). 